\title{
СТАТЕВІ ОСОБЛИВОСТІ ГЕМОГРАМИ ТА ЛІПІДОГРАМИ У ХВОРИХ ІЗ ГОСТРИМ КОРОНАРНИМ СИНДРОМОМ БЕЗ ПІДЙОМУ СЕГМЕНТА SТ НА ТЛІ ЕСЕНЦІАЛЬНОÏ АРТЕРІАЛЬНОÏ ГІПЕРТЕНЗІї, IHФIКOBAHИX HELICOBACTER PYLORI
}

\begin{abstract}
Резюме. Гострий коронарний синдром (ГКС) є важливою причиною інвалідизації та смерті пацієнтів, незважаючи на значні успіхи в діагностиці та лікуванні, причому ГКС без елевації сегмента ST спостерігають частіше і характеризується він удвічі вищими показниками смертності у віддаленому періоді, ніж ГКС з елевацією сегмента ST. До важливих фракторів ризику розвитку ГКС відносять есенціальну артеріальну гіпертензію (ЕАГ), дисліпідемію і системне запалення.

Мета дослідження - вивчити статеві особливості гемограми та ліпідограми у хворих із гострим коронарним синдромом без підйому сегмента ST на тлі есенціальної артеріальної гіпертензії, інфрікованих Helicobacter pylori.

Матеріали і методи. Обстежено 134 хворих віком 45-83 роки з діагнозом гострого коронарного синдрому без підйому сегмента ST на тлі есенціальної артеріальної гіпертензії із диспептичними скаргами відповідно до діючих протоколів ведення гострого коронарного синдрому без підйому сегмента ST, есенціальної артеріальної гіпертензії і диспепсії. Пацієнтів поділили на групи: чоловіків та жінок, інфікованих і неінсрікованих Helicobacter pylori. Контрольну групу склали 30 практично здорових осіб відповідного віку та статі.

Результати досліджень та їх обговорення. За наявності інфекції Helicobacter pylori спостерігали достовірно вираженіше збільшення печінки і вищі показники відношення тромбоцитів до лімфоцитів серед чоловіків, порівняно з жінками, разом 3 тим, як у групах пацієнтів, неінфікованих Helicobacter pylori, достовірних статевих відмінностей серед цих показників ми не виявили. Показники ШОЕ, загального холестеролу, ліпопронеїнів низької щільності, тригліцеридів та коефріцієнт атерогенності плазми були достовірно вищими серед пацієнтів обох статей, інфікованих Helicobacter pylori, порівняно з неінфікованими. Крім того, виявлено достовірно вираженіше збільшення печінки, нижчу фракцію викиду, підвищення ШОЕ і відношення тромбоцитів до лімфроцитів у чоловіків, інфікованих Helicobacter pylori, порівняно з неінфікованими, чого не спостерігали серед жінок. Висновки. Отримані дані вказують на можливе поглиблення серцевої недостатності, дисліпідемії і системного запалення у чоловіків, інфікованих Helicobacter pylori, порівняно з неінфікованими, а також порівняно з жінками, незалежно від фактора інфекції Helicobacter pylori.
\end{abstract}

Ключові слова: гострий коронарний синдром; Helicobacter pylori; чоловіки; жінки; гемограма; ліпідограма.

ВСТУП Гострий коронарний синдром (ГКС) є важливою причиною інвалідизації та смерті пацієнтів, незважаючи на значні успіхи в діагностиці та лікуванні, причому гкС без елевації сегмента ST спостерігають частіше і характеризується він удвічі вищими показниками смертності у віддаленому періоді, ніж ГКС з елевацією сегмента ST. До важливих фракторів ризику розвитку ГКС відносять есенціальну артеріальну гіпертензію (ЕАГ), дисліпідемію і системне запалення [1-3].

Helicobacter pylori (HP) виявляють у близько половини пацієнтів із ГКС, а частота кардіоваскулярних подій серед хворих, серопозитивних щодо НР, у 2,5 раза вища, порівняно 3 серонегативними, а рівень інфрікування НР корелює 3 частотою ранніх ускладнень та летальності у хворих із ГКС. Можливий зв'язок НР і ГКС пояснюють, з одного боку, системними ефектами місцевого запалення слизової оболонки гастродуоденальної зони, а з іншого - хронічною імуннозапальною відповіддю із залученням у процес віддалених структур. Разом з тим, деякі дослідники показали відсутність як статистично достовірної різниці в інсрікуванні НР серед хворих із ГКС, порівняно з контрольною групою, так і кореляції частоти інфрікування HP із такими фракторами ризику IXC, як тютюнокуріння, гіпертензія, цукровий діабет, підвищення загального рівня холестеролу та індексу маси тіла [4].

Відомо, що перебіг хвороб, зокрема ГКС, відрізняється у чоловіків і жінок різного віку. Як поширеність ГКС, так і рівень інфрікування НР є вищим серед чоловіків, крім того, у них частіше реєструють позитивні результати стрес-тесту, вищі показники ранньої смертності та гірший віддалений прогноз порівняно з жінками. Разом із тим, результати окремих досліджень взагалі не виявили достовірної різниці серед показників частоти ранніх ускладнень і шпитальної летальності серед чоловіків та жінок із ГКС без ST [5].

Висока частота ГКС без підйому сегмента ST із фоновою ЕАГ, а також суперечливість літературних даних щодо впливу НР на перебіг ГКС, що майже не досліджували у хворих різної статі, зумовлює особливу актуальність дослідження можливого впливу НР на процеси системного запалення і дисліпідемію у пацієнтів із ГКС без підйому сегмента ST на ЕАГ у чоловіків та жінок.

Метою дослідження було вивчити статеві особливості гемограми та ліпідограми у хворих із гострим коронарним синдромом без підйому сегмента ST на тлі есенціальної артеріальної гіпертензії, інсрікованих Helicobacter pylori.

MATEPIAЛИ I МЕТОДИ Обстежено 134 Хворих (68 чоловіків і 66 жінок) віком 45-83 роки, яких госпіталізували з діагнозом ГКС без підйому сегмента ST та диспептичними скаргами (біль або дискомфорт в епігастрії, нудоту, печію тощо). Медична документація їх містила інформацію про ЕАГ на базах Закарпатського обласного клінічного кардіологічного диспансеру і кардіореанімаційного відділення Центральної міської клінічної лікарні (м. Ужгород). Контрольну групу склали 30 практично здорових осіб відповідного віку і статі.

Обстеження проводили відповідно до діючих клінічних протоколів ведення хворих із ГКС без підйому сегмента ST, ЕАГ і диспепсії з урахуванням міжнародних рекомендацій, зокрема Маастрихтського консенсусу $\vee[1,3,6,7]$. Методи дослідження: загальноклінічні (скарги, анамнез захворювання і життя, фрізикальне обстеження), загальні аналізи крові та сечі, біохімічний аналіз крові, ліпідограма, функціональні (ЕКГ, ХМ ЕКГ), інвазивні (коронарографрія), імунофрерментний аналіз для визначення рівня сумарних антитіл до НР, езофрагогастродуоденоскопія, консультація гастроентеролога. Лабораторні та біохімічні дослідження виконали на основі стандартних методик.

Залежно від титру сумарних антитіл до НР і статі, пацієнтів поділили на 4 групи: чоловіки $\mathrm{HP}+(\mathrm{n}=36$, середній вік $(66,5 \pm 1,77)$ року), чоловіки НР- $(n=32$, середній вік $(68,1 \pm 3,25)$ року), жінки $\mathrm{HP}+(\mathrm{n}=35$, середній вік $(65,02 \pm 3,66)$ року), жінки HP- ( $n=31$, середній вік $(67,63 \pm 3,72)$ року). Групи достовірно 
не відрізнялися за віком. Статистичну обробку даних проводили за допомогою програм Microsoft Office Excell 2010 та Statistica v 8.0 із визначенням середнього значення (M), його стандартної похибки $(\mathrm{m})$ і оцінкою достовірності виявлених змін із використанням парного критерію Стьюдента. Розбіжності вважали істотними при $p<0,05$.

РЕЗУЛЬТАТИ ДОСЛІДЖЕНЬ ТА ЇХ ОБГОВОРЕННЯ Серед чоловіків, інфікованих НР, порівняно з неінфрікованими, виявлено достовірно вираженіше збільшення печінки порівняно з віковою нормою (за даними УЗД органів черевної порожнини) - на $(1,3 \pm 0,25)$ см і $(0,7 \pm 0,26)$ см відповідно ( $<<0,001)$ і нижчу фрракцію викиду $((53,5 \pm 4,51) \%$ i $(57,7 \pm 3,62)$ \% відповідно, p<0,001). Крім того, у групах чоловіків, інорікованих НР, порівняно із жінками, також виявлено достовірно вираженіше збільшення печінки (на $(1,3 \pm 0,25)$ см і $(0,61 \pm 0,26)$ см відповідно, p<0,001). Серед жінок у групах HP+ і HP- достовірної різниці серед цих показників ми не виявили (збільшення печінки на $(0,61 \pm 0,26)$ см і $(0,71 \pm 0,18)$ см відповідно, p>0,05, фрракція викиду - $(53,14 \pm 6,35) \%$ і $(56,67 \pm 3,27) \%$ відповідно, p>0,05), як і не відмічено статевих відмінностей даних показників у групах пацієнтів, неінорікованих НР. Отримані дані можуть вказувати на прогресування серцевої недостатності серед обстежених чоловіків, інфрікованих НР.

Основні показники гемограми із розрахунком співвідношень нейтросрілів до лімфроцитів (H/Л) і тромбоцитів до лімфоцитів (Т/Л), що є високочутливими маркерами системного запалення [8], наведено в таблиці 1.

Серед обстежених чоловіків, інорікованих НР, відмічено достовірно нижчі показники гемоглобіну та еритроцитів і вірогідно вищий рівень тромбоцитів, порівняно 3 неінфрікованими, чого не спостерігалося у групах чоловіків та жінок, неінорікованих НР, хоча ці показники залишалися в межах норми.

Серед пацієнтів обох статей, інфікованих НР, виявлено достовірно вищі показники ШОЕ і Т/Л, порівняно 3 неінорікованими, а серед чоловіків, порівняно $з$ жінками, також лейкоцитів і нейтрофрілів, що може свідчити про вищу інтенсивність запального процесу на тлі інфрекції Helicobacter pylori, особливо у чоловіків. Серед хворих обох статей, неінфрікованих НР, достовірних відмінностей показників ШОЕ, лейкоцитів і Н/Л та Т/Л ми не виявили.

Виявлено достовірну різницю рівнів нейтрофрілів і Н/Л та Т/Л серед жінок, інфрікованих НР, порівняно $з$ неінфікованими, що може свідчити про вищу чутливість даних показників, як маркерів запалення у жінок, порівняно 3 чоловіками. Відношення Т/Л було достовірно вищим у пацієнтів, інфікованих НР, порівняно з неінфікованими, незалежно від статі, тож цей показник, очевидно, $є$ найчутливішим у хворих із ГКС.

Показники ліпідограми наведено в таблиці 2.

Таблиця 1. Окремі показники гемограми у пацієнтів різної статі з гострим коронарним синдромом без підйому сегмента

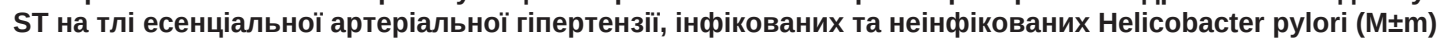

\begin{tabular}{|l|c|c|c|c|}
\hline \multirow{2}{*}{ Показник } & \multicolumn{2}{c|}{ Чоловіки } & \multicolumn{2}{c|}{ Жінки } \\
\cline { 2 - 5 } & $\mathrm{HP}+$ & $\mathrm{HP}-$ & $\mathrm{HP}+$ & $\mathrm{HP}-$ \\
\hline Гемоглобін (г/л) & $139,7 \pm 5,32^{*+}$ & $144,3 \pm 2,66^{+}$ & $128,78 \pm 3,62$ & $130,29 \pm 4,72$ \\
\hline Еритроцити $\left(\times 10^{12} / л\right)$ & $4,8 \pm 0,23^{*}$ & $5,36 \pm 0,43^{+}$ & $4,69 \pm 0,19$ & $4,46 \pm 0,12$ \\
\hline Тромбоцити (х109/л) & $263,43 \pm 25,90^{*+}$ & $230,56 \pm 10,51$ & $224,13 \pm 15,62$ & $244,4 \pm 31,93$ \\
\hline ШОЕ (мм/год) & $19,4 \pm 4,3^{*}$ & $11,3 \pm 2,3$ & $16,22 \pm 2,73^{*}$ & $13,71 \pm 1,1$ \\
\hline Лейкоцити (х10/л) & $8,82 \pm 0,4^{*+}$ & $7,37 \pm 0,83$ & $7,30 \pm 1,02$ & $7,82 \pm 0,93$ \\
\hline Нейтросріли (х109/л) & $4,73 \pm 1,3^{+}$ & $4,71 \pm 0,93^{+}$ & $5,56 \pm 1,31^{*}$ & $3,66 \pm 1,92$ \\
\hline Лімфроцити (х109/л) & $2,27 \pm 0,50$ & $2,37 \pm 0,31$ & $1,88 \pm 0,4$ & $2,34 \pm 1,09$ \\
\hline Н/Л & $2,07 \pm 0,21$ & $2,16 \pm 0,71$ & $2,21 \pm 0,2^{*}$ & $1,81 \pm 0,64$ \\
\hline Т/Л & $144,89 \pm 37,8^{*+}$ & $94,63 \pm 35,05$ & $123,94 \pm 23,76^{*}$ & $108,53 \pm 20,15$ \\
\hline
\end{tabular}

Примітки: 1) * - p<0,05 порівняно $з$ неінфікованими Helicobacter pylori;

2) $+-p<0,05$ порівняно 3 жінками

3) шОЕ - швидкість осідання еритроцитів;

4) Н/Л - відношення нейтрофілів до лімфоцитів;

5) Т/Л - відношення тромбоцитів до лімфоцитів.

Таблиця 2. Окремі показники ліпідограми у хворих різної статі з гострим коронарним синдромом без підйому сегмента

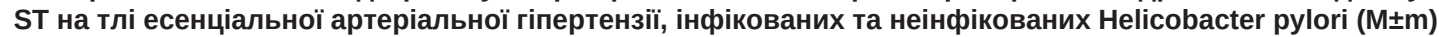

\begin{tabular}{|c|c|c|c|c|}
\hline \multirow{2}{*}{ Показник } & \multicolumn{2}{|c|}{ Чоловіки } & \multicolumn{2}{|c|}{ Жінки } \\
\hline & $\mathrm{HP}+$ & HP- & $\mathrm{HP}+$ & HP- \\
\hline Загальний холестерин (ммоль/л) & $6,44 \pm 4,41^{*}$ & $4,31 \pm 0,34$ & $6,52 \pm 0,33^{*}$ & $4,4 \pm 0,25$ \\
\hline лПНЩ (ммоль/л) & $4,15 \pm 0,29^{*}$ & $2,75 \pm 0,27$ & $3,45 \pm 0,49^{*}$ & $2,8 \pm 0,18$ \\
\hline лПВЩ (ммоль/л) & $1,5 \pm 0,09$ & $1,39 \pm 0,14^{+}$ & $1,27 \pm 0,13^{*}$ & $2,01 \pm 0,36$ \\
\hline ТГ (ммоль/л) & $1,45 \pm 0,14^{*}$ & $1,08 \pm 0,17$ & $1,57 \pm 0,13^{*}$ & $0,99 \pm 0,12$ \\
\hline КА (ум. од.) & $3,23 \pm 0,12^{*}$ & $2,62 \pm 0,18$ & $3,48 \pm 0,19^{*}$ & $2,47 \pm 0,16$ \\
\hline
\end{tabular}

Примітки: 1) * - p<0,05 порівняно з неінфрікованими Helicobacter pylori;

2) $+-p<0,05$ порівняно 3 жінками;

3) лПнЩ - ліпопротеїни низької щільності;

4) лПВЩ - ліпопротеїни високої щільності;

5) ТГ - тригліцериди;

6) КА - коесріцієнт атерогенності. 
У групах чоловіків та жінок, інфікованих НР, порівняно 3 неінфікованими, відмічено достовірно вищі рівні загального холестерину, ліпопротеїнів низької щільності, тригліцеридів, а також коефіцієнт атерогенності, що узгоджується з даними літератури щодо поглиблення дисліпідемії у хворих із ГКС за наявності інфрекції Helicobacter pylori [4].

ВИСНОВКИ 1. У чоловіків із гострим коронарним синдромом на тлі есенціальної артеріальної гіпертензії, інорікованих Helicobacter pylori, спостерігалися достовірно вираженіше збільшення печінки і нижча орракція серцевого викиду, порівняно з неінфікованими, що може свідчити про поглиблення серцевої недостатності за умов інсрекції Helicobacter pylori.

2. У гемограмі обстежених хворих обох статей, інфрікованих Helicobacter pylori, виявлено підвищення ШОЕ i відношення тромбоцитів до лімфоцитів, порівняно 3 неінсрікованими, що може вказувати на вищу інтенсивність запального процесу в цих пацієнтів.
3. Серед обстежених чоловіків, інфрікованих Helicobacter pylori, порівняно з жінками, виявлено вірогідно вищі рівні лейкоцитів і нейтросрілів, а серед жінок, інфрікованих Helicobacter pylori, порівняно з неінфрікованими, відношення нейтрофрілів до лімфоцитів також було збільшеним, що може вказувати на вищу чутливість цього співвідношення як маркера запалення у жінок.

4. Серед пацієнтів обох статей, інфрікованих Helicobacter pylori, виявлено достовірно вищі рівні загального холестерину, ліпопротеїнів низької щільності, тригліцеридів, а також коефіцієнт атерогенності, порівняно 3 неінфрікованими, що може свідчити про поглиблення дисліпідемії на тлі інфекції Helicobacter pylori.

Перспективи подальших досліджень Отримані дані вказують на доцільність скринінгу інфікування Helicobacter pylori в комплексі обстеження чоловіків із гострим коронарним синдромом без підйому сегмента ST на тлі есенціальної артеріальної гіпертензії і дослідити вплив ерацикаційної терапії на показники гемограми та ліпідограми у динаміці.

\section{СПИСОК ЛІТЕРАТУРИ}

1. Гострий коронарний синдром без елевації сегмента ST : унісікований клінічний протокол надання первинної, екстреної та вторинної (спеціалізованої), третинної (високоспеціалізованої) медичної допомоги та медичної реабілітації. - К., 2016. - 79 с.

2. Inflammation and its resolution as determinants of acute coronary syndromes / Peter Libby, Ira Tabas, Gabrielle Fredman, Edward Fisher // Circ. Res. - 2014. - Vol. 114 (12). - P. 1867-1879.

3. Артеріальна гіпертензія : унісікований клінічний протокол надання первинної, екстреної та вторинної (спеціалізованої) медичної допомоги. - К., 2012. - 72 c.

4. Clinical significance of Helicobacter pylori infection in patients with acute coronary syndromes: an overview of current evidence / J. Budzyński, M. Koziński, M. Kłopocka [et al.] // Clin. Res. Cardiol. - 2014. - Vol. 103 (11). - P. 855-886.

5. Pattern of risk factors and management strategies in patients with acute coronary syndrome, in different age groups and sex categories / H. Mansour, A. Reda, M. Mena [et al.] // Atherosclerosis Supp. - 2017. - Vol. 25. - P. e1-e11.

6. Унісрікований клінічний протокол первинної медичної допомоги Диспепсія : наказ Міністерства охорони здоров'я 03.08.2012 № 600 . - К., 2012. - 26 c.

7. Management of Helicobacter pylori infection-the Maastricht V/ Florence Consensus / P. Malfertheiner, F. Megraud, C. A. O'Morain [et al.] // Report. Gut. - 2017. - Vol. 66 (1). - P. 6-30.

8. Sevket Balta The platelet-lymphocyte ratio: A simple, inexpensive and rapid prognostic marker for cardiovascular events / Sevket Balta, Cengiz Ozturk // Platelets. - 2015. - Vol. 26 (7). - P. 680681. DOI: 10.3109/09537104.2014.979340

Отримано 03.08.18

Електронна адреса для листування: shved.marianna@gmail.com

CM. I. Shved

Uzhhorod National University

\section{GENDER DIFFERENCES OF COMPLETE BLOOD COUNT AND LIPID PROFILE IN ACUTE CORONARY SYNDROME WITHOUT ST SEGMENT ELEVATION IN PATIENTS WITH ESSENTIAL ARTERIAL HYPERTENSION AND HELICOBACTER PYLORI INFECTION}

Summary. Acute coronary syndrome (ACS) is an important cause of disability and death of patients, despite significant advances in diagnosis and treatment where ACS without ST elevation segment is observed more often and characterized by twice higher death rate in the long run that ACS with ST elevation syndrome. Essential arterial hypertension, dyslipidemia and systemic inflammation are important risk factors of ACS development.

The aim of the study - to investigate the gender differences of complete blood count and lipid profile features acute coronary syndrome without ST segment elevation patients with essential hypertension and Helicobacter pylori infection.

Materials and Methods. 134 acute coronary syndrome patients (age 45-83 years) with primary arterial hypertension and dyspeptic complaints were investigated in accordance to the current protocols of acute coronary syndrome without ST segment elevation, essential arterial hypertension and dyspepsia management. The patients were divided by the groups of men and women, infected und uninfected with Helicobacter pylori. The control group included 30 healthy persons of the same age and gender.

Results and Discussion. In case of Helicobacter pylori infection the significantly higher hepatomegaly and platelets/lymphocytes ratio were observed in men versus women while in the groups of the patients uninfected with Helicobacter pylori we didn't reveal any significant gender differences of those indices. The ESR, levels of total cholesterol, low density lipoproteins and the atherogenic index of plasma were significantly higher in patients infected with Helicobacter pylori versus uninfected, regardless of gender. In men infected versus uninfected with Helicobacter pylori the significantly higher hepatomegaly, lower ejection fraction, high ESR and platelets/ lymphocytes ratio were revealed that wasn't observed among women. 
Conclusions. The obtained data might indicate the significant progression of heart failure, dyslipidemia and systemic inflammation in men infected with Helicobacter pylori versus uninfected and in men versus women regardless of Helicobacter pylori infection factor.

Key words: acute coronary syndrome; Helicobacter Pylori; men; women; complete blood count; lipid profile.

СМ. И. Швед

ГвУз “Ужгородский национальный университет”

\section{ПОЛОВЫЕ ОСОБЕННОСТИ ГЕМОГРАММЫ И ЛИПИДОГРАММЫ У БОЛЬНЫХ С ОСТРЫМ КОРОНАРНЫМ СИНДРОМОМ БЕЗ ПОДЪЕМА СЕГМЕНТА ЗТ НА ФОНЕ ЭССЕНЦИАЛЬНОЙ АРТЕРИАЛЬНОЙ ГИПЕРТЕНЗИИ, ИНФИЦИРОВАННЫХ HELICOBACTER PYLORI}

Резюме. Острый коронарный синдром (ОКС) является важной причиной инвалидизации и смерти пациентов, несмотря на значительные успехи в диагностике и лечении, причем ОКС без подъемов сегмента ST наблюдают чаще и характеризуется он вдвое более высокими показателями смертности в отдаленном периоде, чем ГКС с элевацией сегмента ST. К важным фракторам риска развития ОКС относят эссенциальную АГ (ЭАГ), дислипидемию и системное воспаление.

Цель исследования - изучить половые особенности показателей гемограммы и липидограммы у мужчин и женщин с острым коронарным синдромом без подъема сегмента ST на фроне эссенциальной артериальной гипертензии, инфрицированных Helicobacter pylori.

Материалы и методы. Обследовано 134 больных 45-83 лет с диагнозом острого коронарного синдрома без подъема сегмента ST и эссенциальной артериальной гипертензии с диспептическими жалобами согласно действующих протоколов ведения острого коронарного синдрома без подъема сегмента ST, эссенциальной артериальной гипертензии и диспепсии. Пациенты были поделены на группы мужчин и женщин, инсицированных и неинфицированных Helicobacter pylori. Контрольную группу составили 30 практически здорових людей соответствующего возраста и пола.

Результаты исследований и их обсуждение. При наличии инсекции Helicobacter pylori наблюдались достоверно более выраженное увеличение печени, а также повышение соотношения тромбоцитов и лимфоцитов среди мужчин, по сравнению с женщинами, в то время как в группах пациентов, неинорицированных Helicobacter pylori, достоверных половых различий этих показателей мы не обнаружили. Показатели СОЭ, общего холестерола, липопротеинов низкой плотности, триглицеридов и коэффрициент атерогенности были достоверно выше среди пациентов, инфрицированных Helicobacter pylori, по сравнению с неинсрицированными, независимо от пола. Среди мужчин, в отличие от женщин, при наличии геликобактерной инфекции обнаружены достоверно более выраженное увеличение печени, снижение фракции выброса, повышение СОЭ и соотношение тромбоцитов и лимсроцитов по сравнению с неинсицированными.

Выводы. Полученные данные указывают на возможное усугубление сердечной недостаточности, дислипидемии и системного воспаления у мужчин, инфицированных Helicobacter pylori, в сравнении с неинсицированными, а также с женщинами, независимо от инфекции Helicobacter pylori.

Ключевые слова: острый коронарный синдром; Helicobacter pylori; мужчины; женщины; гемограмма; липидограмма. 